\title{
Hyperglycemia is independently associated with decreased survival after aneurysmal subarachnoid hemorrhage in Mexican patients
}

\author{
Erwin Chiquete-Anaya ${ }^{1}$, José L. Ruiz-Sandoval2,3*, Antonio Arauz-Góngora4, \\ Fernando Barinagarrementería ${ }^{5}$, Luis M. Murillo-Bonilla ${ }^{6}$, German López-Valencia², \\ Fredy 0. González-Pola ${ }^{7}$, Amado Jiménez-Ruiz' ${ }^{1}$, Alejandro Gutiérrez-Castillo ${ }^{8,9}$, Carlos Cantú-Brito ${ }^{1}$, and \\ the PREMIER Investigators
}

${ }^{1}$ Department of Neurology, Instituto Nacional de Ciencias Médicas y Nutrición Salvador Zubirán, Mexico City; ${ }^{2}$ Department of Neurology, Hospital Civil de Guadalajara "Fray Antonio Alcalde", Guadalajara, Jalisco; ${ }^{3}$ Department of the Translational Neurosciences Institute, Centro Universitario de Ciencias de la Salud, Universidad de Guadalajara, Guadalajara, Jalisco; ${ }^{4}$ Department of Neurology, Stroke Clinic, Instituto Nacional de Neurología y Neurocirugía, Mexico City; ${ }^{5}$ Department of Neurology, Hospital Ángeles de Querétaro, Querétaro; ${ }^{6}$ Department ofNeurology, Instituto Panvascular de Occidente, Guadalajara, Jalisco; ${ }^{7}$ Faculty of Human Medicine, Universidad Autónoma de Chiapas, Tuxtla Gutiérrez, Chiapas, Mexico; ${ }^{8}$ Department of Neurology, Hospital San José, Tecnológico de Monterrey, Nuevo León; ${ }^{9}$ School of Medicine, Instituto Tecnológico y de Estudios Superiores de Monterrey, Monterrey, Nuevo León, Mexico

\begin{abstract}
Background: Hyperglycemia at admission has been recognized as an independent predictor of poor outcome after aneurysmal subarachnoid hemorrhage (aSAH); however, it remains poorly characterized in multivariate models depicting representative population samples. Objective: The objective of the study was to identify if admission blood glucose can independently predict in-hospital mortality after subarachnoid hemorrhage in Mexican patients included in a nationwide multicenter registry. Design/methods: Consecutive patients with aSAH due to ruptured intracranial aneurysm confirmed by 4-vessel angiography were registered in 25 tertiary referral centers from 14 states in Mexico. Multivariate analyses were modeled to find independent predictors of in-hospital mortality, with adjustment for relevant confounders, using the Hunt-Hess and Fisher scales. Results: A total of 231 patients were studied (66\% women; mean age 52 years, range 16-90). Length of hospital stay was a median of 23 days (range 2-98) with in-hospital mortality of $20 \%, 54 \%$ due to a neurological cause. Survival analyses showed a higher probability of death with admittance blood glucose levels in the higher quartile (glycemia > $150 \mathrm{mg} / \mathrm{dl}$ ) $(p<0.001$ ). Predictors of in-hospital mortality were the Hunt-Hess score > 2 (odds ratio [OR]: $3.79,95 \%$ confidence interval [CI]: 1.43-10.06) and glycemia in the higher quartile (OR: 2.98, 95\% Cl: 1.12-7.96). Conclusions: Hyperglycemia is an important independent factor associated with in-hospital mortality. Its early detection and management should be a priority to improve outcomes.
\end{abstract}

Key words: Glucose, Hyperglycemia. Intracranial aneurysm. Subarachnoid hemorrhage. Outcome.

Correspondence:

*José L. Ruiz-Sandoval

E-mail: jorulej-1nj@prodigy.net.mx
Available online: $30-11-2020$

Rev Mex Neuroci. 2020;21(6):217-221

www.revmexneurociencia.com
Date of acceptance: $22-05-2020$

DOI: $10.24875 / R M N .20000016$ 


\section{Hiperglicemia como factor predictor independiente de mayor mortalidad en pacientes mexicanos con hemorragia subaracnoidea aneurismática}

\section{Resumen}

Antecedentes: La hiperglucemia al ingreso se ha reconocido como un predictor independiente de mal pronóstico después de una hemorragia subaracnoidea aneurismática (HSAA); sin embargo, este hallazgo aún está mal caracterizado en modelos multivariados de población representativa. Objetivo: Identificar si la glucosa en sangre al ingreso hospitalario puede predecir de forma independiente la mortalidad hospitalaria después de HSAA en pacientes mexicanos incluidos en un registro multicéntrico nacional. Diseño/métodos: Se registró a pacientes consecutivos con HSA secundaria a un aneurisma intracraneal roto confirmado por angiografía de cuatro vasos en 25 centros de referencia terciarios de 14 estados en México. Los análisis multivariados se modelaron para identificar predictores independientes de mortalidad hospitalaria, con ajuste por factores de confusión relevantes, mediante las escalas de Hunt-Hess y Fisher. Resultados: Se estudió a un total de 231 pacientes (mujeres, 66\%; edad media, 52 años; intervalo, 16-90). La duración de la estancia hospitalaria tuvo una mediana de 23 días (intervalo, 2-98) con una mortalidad hospitalaria del 20\%, 54\% debido a una causa neurológica. Los análisis de supervivencia mostraron una mayor probabilidad de muerte con los valores de glucosa en sangre en el cuartil superior (glucemia > $150 \mathrm{mg} / \mathrm{dl} ; p<0.001$ ). Los predictores de mortalidad hospitalaria fueron la puntuación de Hunt-Hess > 2 (OR, 3.79; IC 95\%, 1.43-10.06) y la glucemia en el cuartil superior (OR, 2.98; IC95\%, 1.12-7.96). Conclusiones: La hiperglucemia es un importante factor independiente relacionado con la mortalidad hospitalaria. Su detección y gestión tempranas deben ser una prioridad para mejorar los resultados.

Palabras clave: Glucosa. Hiperglucemia. Aneurisma intracraneal. Hemorragia subaracnoidea. Pronóstico.

\section{Introduction}

Hyperglycemia is a well-known poor prognostic factor associated with adverse outcomes in neurocritical conditions such as ischemic stroke, even in the absence of known diabetes mellitus. However, its contribution as an independent predictor in aneurysmal subarachnoid hemorrhage $(\mathrm{aSAH})$ is limited ${ }^{1,2}$.

High blood glucose concentration can be present in one-third of patients with aSAH at any given time during hospitalization ${ }^{3-6}$. Retrospective studies have shown that for every $\mathrm{mg}$ increase in glucose over $140 \mathrm{mg} / \mathrm{dL}$, there is an increase in mortality and adverse outcome ${ }^{7}$. In the present study, we aim to analyze the relationship between blood glucose level at admission and in-hospital mortality risk in patients with aSAH.

\section{Materials and methods}

Data were obtained from the prospective hospital-based national multicenter RENAMEVASC registry (Registro Nacional de Enfermedad Cerebral Vascular) study where consecutive patients with all stroke types (ischemic and hemorrhagic) were registered over a 2-year period in 25 tertiary referral centers across the country. A total of 2000 patients were studied ${ }^{8,9}$. For the present analysis, only patients with a diagnosis of aSAH confirmed by 4-vessel angiography were included.
Demographic data, cardiovascular risk factors, clinical presentation at hospital admission (Glasgow Coma Scale and Hunt and Hess scale), radiological characteristics (aneurysm topography by angiography and Fisher score), medical and neurosurgical treatment, in-hospital complications, and final outcome at hospital discharge were also obtained from the original registry 8,9 .

Blood glucose was measured at hospital admission (using the first blood sample before any intervention) and patients were categorized into two groups depending on blood levels: $\leq 150 \mathrm{mg} / \mathrm{ml}(\leq 8.3 \mathrm{mmol} / \mathrm{l})$ and $>150 \mathrm{mg} / \mathrm{ml}$ (> $8.3 \mathrm{mmol} / \mathrm{l})$. The primary outcome was the association of admission blood glycemia with in-hospital mortality. We used the prognostic Hunt-Hess scale, which classifies patients regarding their clinical features using a numbered scale (I to V, asymptomatic to comatose, respectively) and the Fisher scale which uses computed tomography scan findings to classify patients (I to IV, no visible blood in imaging study, diffuse or no subarachnoid blood with intracerebral or intraventricular hematoma, respectively) to predict the risk of developing vasospasm as a basis to determine prognosis. Lower scores on the Hunt-Hess and the Fisher scales indicate better prognosis. The study was approved by the ethical committee of every participating center in the study, cataloged as a no risk study with no intervention. Patient information was obtained under previous authorization by written consent in all cases. 
Table 1. In-hospital mortality based on clinical characteristics and cerebral imaging at hospital admission

\begin{tabular}{|c|c|c|c|c|c|c|c|c|c|c|c|}
\hline \multirow[t]{2}{*}{ Variable } & \multirow[t]{2}{*}{ Total } & \multicolumn{2}{|c|}{ Gender } & \multirow[t]{2}{*}{$\mathrm{p}$ value } & \multicolumn{2}{|c|}{ Age (years) } & \multirow[t]{2}{*}{$p$ value } & \multicolumn{2}{|c|}{ Intrahospital death } & \multirow[t]{2}{*}{$\mathrm{p}$ value } & \multirow{2}{*}{$\begin{array}{c}\text { Multivariate } \\
\text { p value }\end{array}$} \\
\hline & & Male & Female & & $\leq 49$ & $\geq 50$ & & Present & Absent & & \\
\hline $\begin{array}{l}\text { Hunt-Hess scale } \\
\text { Grade I-II, n (\%) } \\
\text { Grade III-V, n (\%) }\end{array}$ & $\begin{array}{l}133(66) \\
69(34)\end{array}$ & $\begin{array}{l}51(74) \\
51(38)\end{array}$ & $\begin{array}{l}82(62) \\
18(26)\end{array}$ & 0.09 & $\begin{array}{l}72(73) \\
26(27)\end{array}$ & $\begin{array}{l}61(59) \\
43(41)\end{array}$ & 0.04 & $\begin{array}{l}14(40) \\
21(60)\end{array}$ & $\begin{array}{c}119(71) \\
48(29)\end{array}$ & $<0.001$ & 0.046 \\
\hline $\begin{array}{l}\text { Fisher scale } \\
\text { Grade I-II, n (\%) } \\
\text { Grade III-IV, n (\%) }\end{array}$ & $\begin{array}{c}52(26) \\
149(74)\end{array}$ & $\begin{array}{l}17(25) \\
52(75)\end{array}$ & $\begin{array}{l}35(26) \\
97(74)\end{array}$ & 0.86 & $\begin{array}{l}28(29) \\
68(71)\end{array}$ & $\begin{array}{l}24(23) \\
81(77)\end{array}$ & 0.34 & $\begin{array}{c}0(0) \\
34(100)\end{array}$ & $\begin{array}{c}52(31) \\
115(69)\end{array}$ & $<0.001$ & 0.997 \\
\hline $\begin{array}{l}\text { Glasgow Coma Scale } \\
13-15, \mathrm{n}(\%) \\
9-12, \mathrm{n}(\%) \\
3-8, \mathrm{n}(\%)\end{array}$ & $\begin{array}{l}149(67) \\
43(19) \\
32(14)\end{array}$ & $\begin{array}{c}61(80) \\
9(12) \\
6(8)\end{array}$ & $\begin{array}{l}88(59) \\
34(23) \\
26(18)\end{array}$ & 0.007 & $\begin{array}{l}78(76) \\
12(11) \\
13(13)\end{array}$ & $\begin{array}{l}71(59) \\
31(25) \\
19(16)\end{array}$ & 0.01 & $\begin{array}{l}17(39) \\
14(33) \\
12(28)\end{array}$ & $\begin{array}{l}132(73) \\
29(16) \\
20(11)\end{array}$ & $<0.001$ & 0.026 \\
\hline $\begin{array}{r}\text { Admission glycemia } \\
\leq 150 \mathrm{mg} / \mathrm{dl}, \mathrm{n}(\%) \\
>150 \mathrm{mg} / \mathrm{dl}, \mathrm{n}(\%)\end{array}$ & $\begin{array}{l}164(75) \\
55(25)\end{array}$ & $\begin{array}{l}55(73) \\
20(27)\end{array}$ & $\begin{array}{c}109(76) \\
35(24)\end{array}$ & 0.70 & $\begin{array}{l}84(43) \\
20(57)\end{array}$ & $\begin{array}{l}65(46) \\
35(54)\end{array}$ & 0.056 & $\begin{array}{l}20(50) \\
20(50)\end{array}$ & $\begin{array}{c}144(80) \\
35(20)\end{array}$ & $<0.001$ & 0.026 \\
\hline
\end{tabular}

aSAH: aneurysmal subarachnoid hemorrhage; Cl: confidence interval.

\section{Statistical analysis}

We grouped patients using quartiles with the following variables: Hunt-Hess scale, Fisher scale, Glasgow Coma Scale, and admission glycemia. Multivariable analyses were modeled to find independent predictors of in-hospital mortality, with adjustment for relevant confounders. All cases were evaluated by a neurologist using the Hunt and Hess score for aSAH to determine the mortality risk associated with the severity of the hemorrhage on imaging studies and their relation with other individual mortality predictors (including glycemia).

\section{Results}

In the original registry, a total of 231 patients (153 [66\%] women and 78 [34\%] men) were included for analysis. Mean age was 51.8 years (median 51 years, range 16-90). A total of $42 \%$ of patients had a prior diagnosis of hypertension and $7 \%$ had a history of diabetes mellitus. History of tobacco use was a present in $35 \%$ of patients. Median duration of hospital stay was 23 days (range 2-98). In-hospital mortality occurred in $20 \%$ of cases; $54 \%$ were due to a neurological cause, $28 \%$ due to a systemic condition (including infection, deep vein thrombosis, pulmonary embolism, and cardiac arrhythmia), and $17 \%$ with both.

Of the total o patients, only 219 have a blood glucose test prior any intervention. A total of $55(25 \%)$ patients had a blood glucose level in the upper quartile $(>8.3 \mathrm{mmol} / \mathrm{l}$ or $>150 \mathrm{mg} / \mathrm{dL}$ ) compared with 164 patients (75\%) with lower glucose level. Mortality occurred in $50 \%$ among patients with hyperglycemia. Higher grades in the Hunt-Hess scale (Grades III-V) and Fisher scale (III-IV) were related to a higher mortality rate $(60 \%$ and $100 \%$, respectively) in comparison with lower grades. A lower score in the Glasgow scale was not related to mortality rate. These subanalyses are shown in table 1. Survival analyses and Kaplan-Meier curves showed a higher probability of in-hospital death with admittance blood glucose level in the higher quartile of the sample $(p<0.001)$ (Fig. 1). After a binary logistic regression model controlled for clinical and laboratory variables identified at hospital presentation, predictors of in-hospital mortality were Hunt-Hess score $>2$ (odds ratio [OR]: 3.79, 95\% confidence interval [CI]: 1.43-10.06) and glycemia in the higher quartile of the sample (OR: 2.98, 95\% Cl: 1.12-7.96) (Table 2).

\section{Discussion}

Hyperglycemia as a poor prognosis variable in patients with aSAH was first mentioned in $1925^{10}$. Since then, it has been related to non-neurological systemic complications, delayed vasospasm, cerebral infarction, prolonged in-hospital stay, poor functional outcome, and death. Admittance and perioperative blood glucose have been associated with a poor prognosis after aSAH ${ }^{11}$. Despite this early observation, the relationship has been scarcely investigated in other studies (Table S1). Hyperglycemia represents the metabolic response to stress ${ }^{12-14}$ and is associated with a higher risk of vasospasm and secondary ischemia ${ }^{15,16}$. It is 


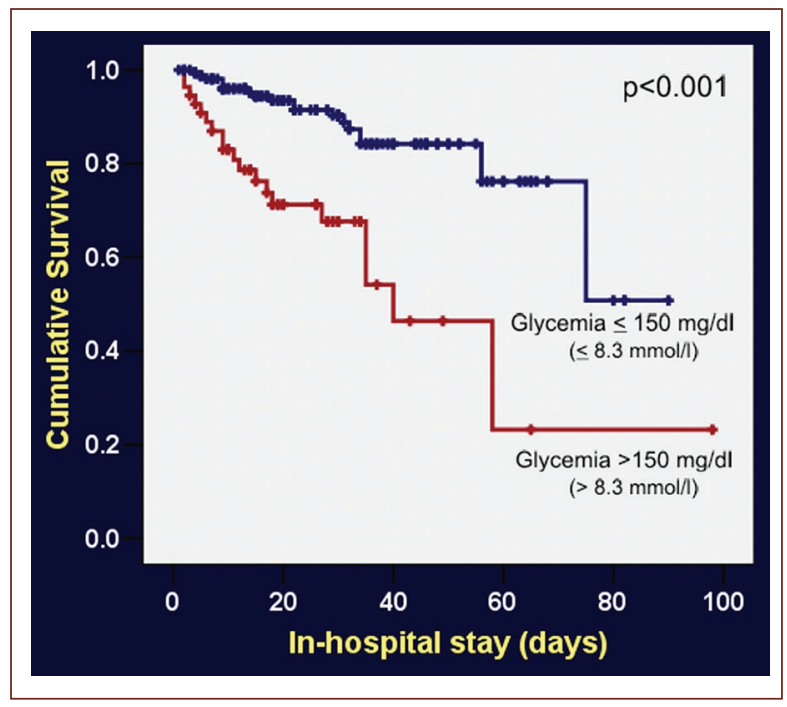

Figure 1. Kaplan-Meier cumulative survival curves in patients with aneurysmal subarachnoid hemorrhage with or without hyperglycemia.

Table 2. Multivariate analysis on factors predicting in-hospital mortality after aSAH: binary logistic regression model

\begin{tabular}{|l|c|c|}
\hline Variable & $\begin{array}{c}\text { Multivariate odds } \\
\text { ratios }(95 \% \text { CI) }\end{array}$ & p value \\
\hline Glycemia $>8.3 \mathrm{mmol} / \mathrm{l}(>150 \mathrm{mg} / \mathrm{dl})$ & $2.98(1.12-7.96)$ & 0.03 \\
\hline Hunt-Hess $>2$ & $3.80(1.43-10.06)$ & 0.007 \\
\hline
\end{tabular}

aSAH: aneurysmal subarachnoid hemorrhage; $\mathrm{Cl}$ : confidence interval.

difficult to determine if hyperglycemia is the cause, the consequence or an epiphenomenon related to medical complications such as pneumonia. Therefore, admittance blood glucose concentration (before several metabolic and medical complications occur) could better define the role that hyperglycemia plays in the outcome of patients with $\mathrm{SAH}$, particularly in those with ruptured aneurysms, after controlling for several factors known to affect the outcome in this condition.

Although in-hospital hyperglycemia has been accepted as a well-characterized contributing poor prognostic and death predictor in the neurosurgical critically ill patients, the role of admission glucose levels is not well described in aSAH, remaining poorly characterized in multivariate models of representative population samples ${ }^{13,17-19}$.

The relationship between hyperglycemia and poor outcomes has been well described in ischemic stroke and is associated with infarct expansion, worse functional outcome, increased length of hospital stay, and death ${ }^{19-21}$. Multiple pathophysiological pathways including vascular inflammatory reactions and free radical production lead to cell death and loss of viable brain tissue after stroke ${ }^{22-24}$. Vasospasm, one of the most feared complications in aSAH related to delayed ischemia and infarction, is present in up to $20 \%$ of patients ${ }^{25,26}$.

Recent studies have demonstrated that elevated blood glucose causes dysregulation of certain enzymes including endothelial nitric oxide (NO) synthase and induced NO synthase. The resulting endothelial damage promotes NO depletion and contributes to secondary vasospasm ${ }^{27}$. Despite several studies describing the occurrence of hyperglycemia and negative outcomes in aSAH, the association of admission glucose with in-hospital mortality has not been described yet. Our study is the first of its kind in Mexican population to test this hypothesis- $2-5,7,12,14-20,24,25,28-31$.

In our study, we found that the blood glucose levels at admission yield important information on mortality and prognosis. There are several useful scores available that include clinical and radiological information (Hunt-Hess score and Fisher score) which are routinely used as a prognostic tool, but none of them include admission glucose levels. Glucose testing is cheap, readily available, and routinely performed in all centers. Based on these results and the available literature, hyperglycemia should be one of the most critical management targets in patients with aSAH. Regarding the actual evidence, glucose control might help prevent vasospasm and subsequently brain infarct and other in-hospital complications that contribute to the currently poor outcome of this disease ${ }^{32}$. Early detection and management of hyperglycemia in patients with aSAH should be a primary target in the management of these patients in an effort to improve clinical outcomes.

\section{Conclusions}

Hyperglycemia is an important independent risk factor associated with in-hospital mortality and adverse prognosis after aSAH. More prospective controlled studies are required to support these results and determine how glucose control might affect mortality and functional prognosis in patients with aSAH. The main limitation of this study is the lack of control of confounding factors as the diabetes mellitus disease control status and medication in patients with this diagnosis. 


\section{Funding}

This research has not received any specific grant from agencies in the public, commercial, or non-profit sectors.

\section{Conflicts of interest}

None to report.

\section{Ethical disclosures}

Protection of human and animal subjects. The authors declare that the procedures followed were in accordance with the regulations of the relevant clinical research ethics committee and with those of the Code of Ethics of the World Medical Association (Declaration of Helsinki).

Confidentiality of data. The authors declare that they have followed the protocols of their work center on the publication of patient data.

Right to privacy and informed consent. The authors have obtained the written informed consent of the patients or subjects mentioned in the article. The corresponding author is in possession of this document.

\section{Supplementary data}

A systematic review of studies about the association between glycemia and SAH is include in Table S1.

Supplementary data are available at Revista Mexicana de Neurociencia online (www.revmexneurociencia.com/index.php). These data are provided by the corresponding author and published online for the benefit of the reader. The contents of supplementary data are the sole responsibility of the authors.

\section{References}

1. Hop JW, Rinkel GJ, Algra A, van Gijn J. Case-fatality rates and functional outcome after subarachnoid hemorrhage: a systematic review. Stroke. 1997;28:660-4.

2. Piironen K, Putaala J, Rosso C, Samson Y. Glucose and acute stroke: evidence for an interlude. Stroke. 2012;43:898-902.

3. Lanzino G, Kassell NF, Germanson T, Truskowski L, Alves W. Plasma glucose levels and outcome after aneurysmal subarachnoid hemorrhage. J Neurosurg. 1993;79:885-91.

4. Juvela S, Siironen J, Kuhmonen J. Hyperglycemia, excess weight, and history of hypertension as risk factors for poor outcome and cerebral infarction after aneurysmal subarachnoid hemorrhage. J Neurosurg. 2005;102:998-1003.

5. Alberti O, Becker R, Benes L, Wallenfang T, Bertalanffy H. Initial hyperglycemia as an indicator of severity of the ictus in poor-grade patients with spontaneous subarachnoid hemorrhage. Clin Neurol Neurosurg. 2000;102:78-83.

6. Steiner T, Juvela S, Unterberg A, Jung C, Forsting M, Rinkel G. European Stroke Organization guidelines for the management of intracranial aneurysms and subarachnoid haemorrhage. Cerebrovasc Dis. 2013;35:93-112.
7. Sayantani G, Saugat D, Mitchell M, Vibbert M, Jallo J. Relationship between serum and csf glucose in subarachnoid hemorrhage. Int J Collab Res Intern Med Public Health. 2012;4:813-8.

8. Ruiz-Sandoval JL, Cantú C, Chiquete E, León-Jiménez C, Arauz A, MuriIlo-Bonilla LM, et al, RENAMEVASC Investigators. Aneurysmal subarachnoid hemorrhage in a Mexican multicenter registry of cerebrovascular disease: the RENAMEVASC study. J Stroke Cerebrovasc Dis. 2009;18:48-55.

9. Cantú-Brito C, Ruiz-Sandoval JL, Chiquete E, León-Jimenez E, MuriIlo-Bonilla LM, Villarreal-Carreaga J, et al. Factores de riesgo, causas y pronóstico de los tipos de enfermedad vascular cerebral en México: estudio RENAMEVASC. Rev Mex Neuroci. 2011;12:224-34.

10. Nicolaysen L. Glykosurie bei meningealer blutung. Acta MedScan. 1925;62:392-4.

11. Macdonald RL, Pluta RM, Zhang JH. Cerebral vasospasm after subarachnoid hemorrhage: the emerging revolution. Nat Clin Pract Neurol. 2007;3:256-63.

12. Mees SM, van Dijk GW, Algra A, Kempink DR, Rinkel GJ. Glucose levels and outcome after subarachnoid hemorrhage. Neurology. 2003;61:1132-3

13. Helbok R, Schmidt JM, Kurtz P, Hanafy KA, Fernandez L, Stuart RM, et al. Systemic glucose and brain energy metabolism after subarachnoid hemorrhage. Neurocrit Care. 2010;12:317-23.

14. Pérez-Neri I. Relevance of hyperglycemia on the course and outcome of aneurysmal subarachnoid hemorrhage: evidence and mechanisms. Invest Clin. 2014;55:278-88.

15. Kruyt ND, Roos YW, Mees SM, van den Bergh WM, Algra A, Rinkel GJ, et al High mean fasting glucose levels independently predict poor outcome and delayed cerebral ischemia after aneurysmal subarachnoid haemorrhage. J Neurol Neurosurg Psychiatry. 2008;79:1382-5.

16. McGirt MJ, Woodworth GF, Ali M, Than KD, Tamargo RJ, Clatterbuck RE. Persistent perioperative hyperglycemia as an independent predictor of poor outcome after aneurysmal subarachnoid hemorrhage. J Neurosurg. 2007;107:1080-5.

17. Badjatia N, Topcuoglu MA, Buonanno FS, Smith EE, Nogueria RG, Rordorf GA, et al. Relationship between hyperglycemia and symptomatic vasospasm after subarachnoid hemorrhage. Crit Care Med. 2005;33:1603-9.

18. Claassen J, Kreiter KT, Kowalski RG, Du EY, Ostapkovich N, Fitzsimmons BF, et al. Effect of acute physiologic derangements on outcome after subarachnoid hemorrhage. Crit Care Med. 2004;32:832-8.

19. Frontera JA, Fernandez A, Claassen J, Schmidt M, Schumacher HC Warternberg K, et al. Hyperglycemia after SAH: predictors, associated complications, and impact on outcome. Stroke. 2006;37:199-203.

20. Al-Khindi T, Macdonald RL, Schweizer TA. Cognitive and functional outcome after aneurysmal subarachnoid hemorrhage. Stroke. 2010;41:e519-36.

21. Passier PE, Visser-Meily JM, Rinkel GJ, Lindeman E, Post MW. Life satisfaction and return to work after aneurysmal subarachnoid hemorrhage. J Stroke Cerebrovasc Dis. 2011;20:324-9.

22. Chan PH, Schmidley JW, Fishman RA, Longar SM. Brain injury, edema, and vascular permeability changes induced by oxygen-derived free radicals. Neurology. 1998;34:315-20.

23. Araki N, Greenberg JH, Sladky JT, Uematsu D, Karp A, Reivich M. The effect of hyperglycemia on intracellular calcium in stroke. J Cereb Blood Flow Metab. 1992;12:469-76.

24. Parsons MW, Barber PA, Desmond PM, Baird TA, Darby DG, Byrnes G, et al. Acute hyperglycemia adversely affects stroke outcome: a magnetic resonance imaging spectroscopy study. Ann Neurol. 2002;52:20-8.

25. Crowley RW, Medel R, Dumont AS, llodigwe D, Kassel NF, Mayer SA, et al. Angiographic vasospasm is strongly correlated with cerebral infarction after subarachnoid hemorrhage. Stroke. 2011;42:919-23.

26. Nakae R, Yokota H, Yoshida D, Teramoto A. Transcranial Doppler ultrasonography for diagnosis of cerebral vasospasm after aneurysmal subarachnoid hemorrhage: mean blood flow velocity ratio of the ipsilateral and contralateral middle cerebral arteries. Neurosurgery. 2011;69:876-83.

27. Huang $\mathrm{YH}$, Chung $\mathrm{CL}$, Tsai HP, Wu SC, Chang CZ, Chai CY, et al. Hyperglycemia aggravates cerebral vasospasm after subarachnoid hemorrhage in a rat model. Neurosurgery. 2017;80:809-15.

28. Kruyt ND, Biessels GJ, de Haan RJ, Vermeulen M, Rinkel GJ, Coert B et al. Hyperglycemia and clinical outcome in aneurysmal subarachnoid hemorrhage: a meta-analysis. Stroke. 2009;40:e424-30.

29. Beseoglu K, Steiger HJ. Elevated glycated hemoglobin level and hyperglycemia after aneurysmal subarachnoid hemorrhage. Clin Neurol Neurosurg. 2017; 163:128-32.

30. Schmutzhard E, Rabinstein AA, Participants in the International Multi-disciplinary Consensus Conference on the Critical care Management of Subarachnoid Hemorrhage. Spontaneous subarachnoid hemorrhage and glucose management. Neurocrit Care. 2011;15:281-6.

31. Capes SE, Hunt D, Malmberg K, Pathak P, Gerstein HC. Stress hyperglycemia and prognosis of stroke in nondiabetic and diabetic patients: a systematic overview. Stroke. 2001;32:2426-32.

32. Matano F, Fujiki Y, Mizunari T, Koketsu K, Tamaki T, Murai Y, et al. Serum glucose and potassium ratio as risk factors for cerebral vasospasm afteraneurysmal subarachnoid hemorrhage. J Stroke Cerebrovasc Dis. 2019;28:1951-7. 


\section{Hyperglycemia is independently associated with decreased survival after aneurysmal subarachnoid hemorrhage in Mexican patients}

Erwin Chiquete-Anaya ${ }^{1}$, José L. Ruiz-Sandoval ${ }^{2,3 *}$, Antonio Arauz-Góngora ${ }^{4}$,

Fernando Barinagarrementería ${ }^{5}$, Luis M. Murillo-Bonilla ${ }^{6}$, German López-Valencia ${ }^{2}$

Fredy O. González-Pola ${ }^{7}$, Amado Jiménez-Ruiz ${ }^{1}$, Alejandro Gutiérrez-Castillo ${ }^{8,9}$, Carlos Cantú-Brito ${ }^{1}$, and the PREMIER Investigators

${ }^{1}$ Department of Neurology, Instituto Nacional de Ciencias Médicas y Nutrición Salvador Zubirán, Mexico City; ${ }^{2}$ Department of Neurology, Hospital Civil de Guadalajara "Fray Antonio Alcalde", Guadalajara, Jalisco; ${ }^{3}$ Department of the Translational Neurosciences Institute, Centro Universitario de y Neurocirugia, Mexico City; ${ }^{5}$ Department of Neurology, Hospital Jilisco; ${ }^{4}$ Department of Neurology, Stroke Clinic, Instituto Nacional de Neurología de Occidente, Guadalajara, Jalisco; '7Faculty of Human Medicine, Universidad Autónoma de Chiapas, Tuxtla Gutiérrez, Chiapas, Mexico; ${ }^{8}$ Department of Neurology, Hospital San José, Tecnológico de Monterrey, Nuevo León; ${ }^{9}$ School of Medicine, Instituto Tecnológico y de Estudios Superiores de Monterrey, Monterrey, Nuevo León, Mexico

Supplementary material

Table S1. Systematic review of studies of association glycemia and SAH (1993-2017 years)

\begin{tabular}{|c|c|c|c|c|}
\hline Year & Author & Sample size (n) & Primary aim & Related results \\
\hline 1993 & Lazino et al. ${ }^{3}$ & 616 & $\begin{array}{l}\text { - Prospective analysis: to determine } \\
\text { the role of admission } \\
\text { hyperglycemia in aSAH prognostic }\end{array}$ & $\begin{array}{l}\text { - Hyperglycemia }(>120 \mathrm{mg} / \mathrm{dL} \text { L) predicted poor } \\
\text { outcome in comparison with normal glucose levels: } \\
\text { in good recovery } 53.7 \% \text { versus } 70.2 \%(p=0.002) \text { and } \\
\text { death rate } 19.9 \% \text { versus } 6.7 \%(p=0.001)\end{array}$ \\
\hline 2000 & $\begin{array}{l}\text { Alberti } \\
\text { et al. } .^{5}\end{array}$ & 99 & $\begin{array}{l}\text { - Prospective analysis: to } \\
\text { demonstrtate hyperglycemia as a } \\
\text { sign of central metabolic } \\
\text { disturbance linked with different } \\
\text { brain injury degree appearances } \\
\text { on CT scans in spontaneous SAH }\end{array}$ & $\begin{array}{l}\text { - Patients with mild } C T \text { findings }(n=10) \text { had a lowest } \\
\text { glucose level (mean } \pm \text { SD) }(8.9 \pm 1.8 \mathrm{mmol} / / ; \\
p=0.0082) \text {, whereas a higher glucose level } \\
(111.4 \pm 3.5 \mathrm{mmol} / / ; ; p=0.011) \text { were associated with } \\
\text { severe CT findings }\end{array}$ \\
\hline 2001 & $\begin{array}{l}\text { Capes } \\
\text { et al. }{ }^{32}\end{array}$ & 32 studies & $\begin{array}{l}\text { - Meta-analysis: to demonstrate the } \\
\text { association between stroke } \\
\text { (ischemic and/or hemorrhagic) } \\
\text { with admission serum glucose } \\
\text { level }\end{array}$ & $\begin{array}{l}\text { - An admission glucose level > 6-8 mmol/L (108-144 } \\
\text { mg/dL) represents an RR of } 3.07 \text { for in-hospital } \\
\text { 30-day mortality in non-diabetic patients and of } 1.30 \\
\text { in diabetic patients }\end{array}$ \\
\hline 2003 & Mees et al..$^{12}$ & 337 & $\begin{array}{l}\text { - Cohort study: to investigate the } \\
\text { relationship between blood } \\
\text { glucose levels, baseline } \\
\text { characteristics, and outcome in } \\
\text { SAH }\end{array}$ & $\begin{array}{l}\text { - Blood glucose level was higher in patients with poor } \\
\text { condition on admission } \\
\text { - The multivariate analysis did not show relation of } \\
\text { glucose levels as an independent poor outcome } \\
\text { predictor }\end{array}$ \\
\hline 2004 & $\begin{array}{l}\text { Claassen } \\
\text { et al. }{ }^{18}\end{array}$ & 413 & $\begin{array}{l}\text { - Consecutive cohort study: to } \\
\text { determine the effect of acute } \\
\text { physiologic derangements on } \\
\text { outcome after SAH }\end{array}$ & $\begin{array}{l}\text { - Serum glucose }>180 \mathrm{mg} / \mathrm{dLL} \text { (OR } 2.8,95 \% \mathrm{Cl}, 1.6-4.8 \text { ) } \\
\text { was independently associated with death or } \\
\text { disability (shown as mRS 4-6, at } 3 \text { months) }\end{array}$ \\
\hline 2005 & $\begin{array}{l}\text { Juvela } \\
\text { et al. }{ }^{4}\end{array}$ & 175 & $\begin{array}{l}\text { - Prospective analysis: to test } \\
\text { whether hyperglycemia, } \\
\text { overweight, and hypertension } \\
\text { affect patient outcomes and the } \\
\text { occurrence of cerebral infarction } \\
\text { after SAH }\end{array}$ & $\begin{array}{l}\text { - The glucose levels at admission predicted a poor } \\
\text { outcome (per mmol/L), the OR was } 1.24 \text { with } 95 \% \mathrm{Cl} \\
\text { of } 1.02-1.51\end{array}$ \\
\hline 2005 & $\begin{array}{l}\text { Badjatia } \\
\text { et al. }{ }^{17}\end{array}$ & 352 & $\begin{array}{l}\text { - Retrospective observational study: } \\
\text { to determine the relationship } \\
\text { between blood glucose levels and } \\
\text { occurrence of symptomatic } \\
\text { vasospasm and clinical outcomes } \\
\text { after aSAH }\end{array}$ & $\begin{array}{l}\text { - Mean admission blood glucose }(176 \pm 40.3 \mathrm{mg} / \mathrm{dL} \text { vs. } \\
162.3 \pm 47.8, \mathrm{p}=0.01) \text { and inpatient } \pm \text { bood glucose } \\
(166.2 \pm 24.7 \mathrm{mg} / \mathrm{dL} \text { vs. } 155.8 \pm 29.7, \mathrm{p}=0.001) \text { levels } \\
\text { were higher in patients with clinical vasosspasm } \\
\text { - Hyperglycemia was associated with voorer autcome } \\
\text { at discharger (mRS }>\text { or }=3: 58.9 \% \text { vs. } 18.8 \% ; p<0.001)\end{array}$ \\
\hline 2006 & $\begin{array}{l}\text { Frontera } \\
\text { et al. }{ }^{19}\end{array}$ & 281 & $\begin{array}{l}\text { - Cohort study: to demonstrate } \\
\text { whether the mean glucose burden } \\
\text { (GB) (defined as an average peak } \\
\text { daily glucose level > } 5.8 \text { mmol/L) } \\
\text { contributes to in-hospital } \\
\text { complications and poor outcome } \\
\text { after SAH }\end{array}$ & $\begin{array}{l}\text { - GB was associated with an increased intensive care } \\
\text { unit length of stay ( } \mathrm{p}=0.0003 \text { ) and other } \\
\text { complicatitions : congestive heart failure, respiratory } \\
\text { failure, pneumonia, and brain stem compression } \\
\text { from herniation (all } p>0.05 \\
\text { - GB was an independent predictor of death (OR 1.10/ } \\
\mathrm{mmol} / \mathrm{L} ; 95 \%, \mathrm{Cl}, 1.01-1.21 ; \mathrm{p}=0.027 \text { ) }\end{array}$ \\
\hline 2007 & $\begin{array}{l}\text { McGirt } \\
\text { et al.16 }\end{array}$ & 97 & $\begin{array}{l}\text { - Prospective analysis: to clarified } \\
\text { whether a single hyperglycemic } \\
\text { event or persistent hyperglycemia } \\
\text { is predictive of poor outcome } \\
\text { after aSAH }\end{array}$ & $\begin{array}{l}\text { - Isolated hyperglycemic levels did not predict poor } \\
\text { outcome } \\
\text { - Patients with persistent hyperglycemia were 7-fold } \\
\text { more likely to have a poor outcome a mean } 10 \\
\text { months after aSAH }\end{array}$ \\
\hline 2008 & $\begin{array}{l}\text { Kruyt } \\
\text { et al. }{ }^{15}\end{array}$ & 265 & $\begin{array}{l}\text { - Prospective database analysis: } \\
\text { to assess whether levels of } \\
\text { mean fasting glucose within the } \\
1^{\text {st }} \text { week of admission predict } \\
\text { poor outcome and delayed } \\
\text { cerebral ischemia (DCI) in SAH } \\
\text { patients }\end{array}$ & $\begin{array}{l}\text { - The } O R \text { intervals for poor outcome were } 1.9-1.6 \text { for } \\
\text { high admission glucosea and } 3.5-2.5 \text { for high mean } \\
\text { fasting glucose (95\% CI). } \\
\text { - The HR intervals for DCI were 1.7-1-4 for high } \\
\text { admission glucose and 2.0-1.7 for high mean } \\
\text { fasting glucose }\end{array}$ \\
\hline 2009 & $\begin{array}{l}\text { Kruyt } \\
\text { et al. }{ }^{28}\end{array}$ & $\begin{array}{c}17 \text { studies } \\
\text { (4095 patients) }\end{array}$ & $\begin{array}{l}\text { - Meta-analysis: to investigate the } \\
\text { relation between admission } \\
\text { hyperglycemia and outcome } \\
\text { after SAH }\end{array}$ & $\begin{array}{l}\text { - The mean admission glucose level was } 9.3 \mathrm{mmol} / \mathrm{L} \\
\text { (range, } 7.4-1010.0 \mathrm{mmol} / \mathrm{L} \text { ) and the median proportion } \\
\text { of patients with hyperglycemia was } 69 \% \text { (range } \\
29-100 \% \text { ) } \\
\text { - The pooled OR (8 studies) was } 3.1 \text { 195\% Cl, 2.3-4.3) } \\
\text { for poor outcome associated with hyperglycemia }\end{array}$ \\
\hline 2010 & $\begin{array}{l}\text { Helbok } \\
\text { et al. }{ }^{13}\end{array}$ & 28 & $\begin{array}{l}\text { - Prospective consecutive study } \\
\text { with multimodality monitoring of } \\
\text { comatose SAH patients: to } \\
\text { determine if metabolic crisis } \\
\text { (MC) and lactate-pyruvate ratio } \\
\text { (LPR) are associated with } \\
\text { reductions in serum glucose }\end{array}$ & $\begin{array}{l}\text { - Reductions in serum glucose of } 25 \% \text { or more were } \\
\text { associated with new onset } \mathrm{MC}(\mathrm{OR} 3.5,95 \% \mathrm{Cl} \text {, } \\
2.2-6.0) \text { and with an } \mathrm{LPR} \text { rise }(\mathrm{OR} 1.6,95 \% \mathrm{Cl}, 1.1-2.4 \\
\text { - The brain energy metabolic crisis and } \mathrm{LPR} \\
\text { elevation may be associated with poor-grade SAH } \\
\text { patients }\end{array}$ \\
\hline 2012 & $\begin{array}{l}\text { Sayantani } \\
\text { et al. }\end{array}$ & 2000 & $\begin{array}{l}\text { - Retrospective study from a } \\
\text { prospective database: to } \\
\text { determine the relationship } \\
\text { between serum and } \\
\text { cerebrospinal fluid (CSF) } \\
\text { glucose levels and outcome in } \\
\text { aSAH }\end{array}$ & 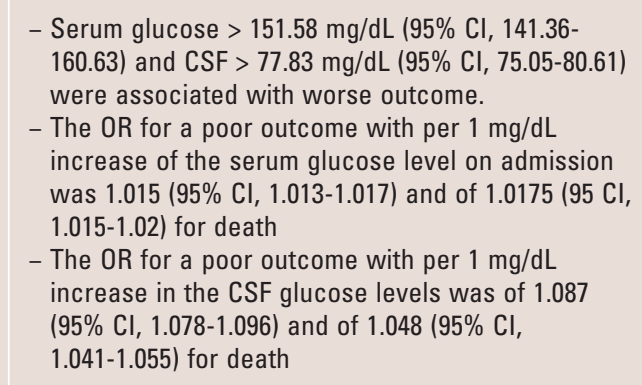 \\
\hline 2017 & $\begin{array}{l}\text { Beseoglu } \\
\text { et al. }{ }^{29}\end{array}$ & 87 & $\begin{array}{l}\text { - Prospective analysis: to } \\
\text { demonstrate the influence of } \\
\text { glycated hemoglobin (HbA1c) on } \\
\text { outcome of patients with aSAH }\end{array}$ & $\begin{array}{l}\text { - HbA1c levels did not correlate with initial } \\
\text { neurological status }(p=0.338, r=0.104) \text {, the } \\
\text { occurrence of delayed cerebral ischemia }(p=0.400) \text {, } \\
\text { or outcome at } 6 \text { months (using mRS) (p=0.790) }\end{array}$ \\
\hline
\end{tabular}

